This is an Accepted Manuscript of an article published by Taylor \& Francis in Journal of Gender Studies on June $3^{\text {rd }}, 2013$, available online: http://doi.org/10.1080/09589236.2013.803952

\title{
Societies in transition: are they more sexist? A comparison between Polish, South African and British samples
}

\author{
Magdalena Zawisza ${ }^{\mathrm{a} *}$, Russell Luyt ${ }^{\mathrm{a}}$ and Anna Maria Zawadzka ${ }^{\mathrm{b}}$ \\ ${ }^{a}$ Department of Psychology, University of Winchester, Sparkford Road, Herbert Jarman Building, \\ Winchester SO224NR, UK; ' Department of Psychology, University of Gdansk, Gdansk, Poland
}

\begin{abstract}
This study investigates ambivalent sexism to women in student samples from two under-researched transitional countries, Poland (PL) and South Africa (SA), in comparison with the United Kingdom. Based on ambivalent sexism theory (AST), and in light of socio-economic context, it was hypothesised that: (1) the sample in PL and SA would be more hostile- and benevolent-sexist than the sample from the UK, (2) males would exhibit more hostile attitudes than females irrespective of country and (3) males would outscore females on benevolent attitudes in the relatively liberal UK but underscore them in relatively conservative SA. The Ambivalent Sexism Inventory was used to measure benevolent and hostile sexism. The findings largely supported the hypotheses. The participants in SA and PL were more sexist than in the UK and men were more hostile-sexist than women in all three countries. However, males outscored females on benevolent sexism not only in the UK but also in SA and PL. Moreover, the sample from PL was observed to be more sexist than the sample from SA. The findings are discussed in light of AST and the countries' transitional context.
\end{abstract}

Keywords: ambivalent sexism; gender attitudes; transition to democracy; Poland; South Africa; United Kingdom

A great deal of research has examined gender attitudes cross-nationally (see Williams and Best 1982, Williams et al. 1999, Glick et al. 2004), and, in particular, attitudes towards women (see Tougas et al. 1995, Glick and Fiske 1996, Glick et al. 2000, Twenge 2001, Swim and Campbell 2003). However, with a few exceptions, this research has neglected study of gender attitudes in 'transitional' (see below) countries such as those from Central and Eastern Europe (CEE) (for example Poland, Smith and Bond 1999) and Africa [for example, South Africa (SA), Glick et al. 2000]. In addition, the research has largely understood gender attitudes as a global construct, failing to distinguish between hostile sexism (HS) and benevolent sexism (BS) (that is overt negativity and evaluatively positive but patronising attitudes to women; see Glick and Fiske 1996). Importantly, a discussion of how the dynamic socio-cultural context of transitional countries may influence the manifestation of sexism has been neglected. The aim of this paper is to address these gaps in the literature by examining both HS and BS to women in transitional Poland (PL) and SA in contrast to the relatively socio-politically stable UK.

PL and SA were specifically selected as they have undergone socio-economic and political transition during the same period after an interval of economic and political

*Corresponding author. Email: magdalena.zawisza@winchester.ac.uk

isolation. Importantly, however, these countries differed in the emphasis afforded gender issues during transition. The term 'transition', when applied to countries, traditionally refers to instances characterised by constitutional reform including market-oriented changes (Falke 2002). While this normally involves movement from a centrally planned to a freemarket economy (Cameron 2003) - as seen, for example, in CEE countries - it can also be observed in post-colonial or post-authoritarian systems (Falke 2002). Thus, transition can 
This is an Accepted Manuscript of an article published by Taylor \& Francis in Journal of Gender Studies on June $3^{\text {rd }}$, 2013, available online: http://doi.org/10.1080/09589236.2013.803952

include profound political reform within an already existing free-market economy, as was the case in SA (Cameron 2003). According to Burgess and Steenkamp (1999, p. 2) in SA:

(t)here are clear parallels to the situation in Eastern Europe. In the former communist countries there was also a clear distinction between the elite (i.e., Communist Party members) and the majority of the population. In Eastern Europe, economic and political freedom of the majority of the population was also severely restricted. Moreover, the concentration in South Africa of economic power in a few hands is in important respects similar to (pretransition) Eastern Europe.

Of specific relevance here, and despite these similarities, varying emphasis afforded gender issues in SA and PL during their respective transitions. A comparison of these provides a unique opportunity to analyse how the nature of transition - a history of legalised inequality in SA as against the forced emancipation of communism in PL - may shape the manifestation of benevolent and HS among men and women.

Our analysis goes beyond the predictions of ambivalent sexism theory (AST; Glick and Fiske 1996, Glick et al. 2000). This theory assumes that the origins of HS and BS are biological (sexual dimorphism) and social (patriarchy) where the former lead to the latter and result in ambivalent sexism cross-culturally (Glick et al. 2000). AST does acknowledge that

(t)he degree of hostile as compared with benevolent sexism may vary widely among societies (from those in which women are treated as chattel to those dominated by an ideology of chivalry) [... ]. (Glick and Fiske 1996, p. 492)

Yet, it does not provide a clear account as to why levels of patriarchy (and thus sexism) differ cross-culturally. For example, the authors do not test for possible significant differences in sexisms between countries and, instead, focus more narrowly on the correlations between HS and BS within countries. We also attempt to move beyond modernisation theories. These propose that technological advancements, and related economic changes, may result in altered moral and cultural values, for example, greater gender liberalism (Inglehart and Norris 2003). Specifically, we argue that despite modernisation having taken place during the same period in each country, the degree of gender liberalism differs, as mentioned above, as a consequence of the varying emphasis afforded to gender issues in each.

Our analysis thus focuses on two key questions: (1) what is the level of HS and BS in PL and SA as compared to that in the UK and (2) how do men compare to women concerning their benevolent and hostile sexist attitudes towards women in each of the three countries? Additionally, our data will enable indirect confirmation of previous findings reporting the UK's relative gender egalitarianism and SA's relative gender conservatism (Glick et al. 2000), as well as provide an examination of potential changes over time across these two countries.

The manifestation of sexism towards women around the world

According to AST (Glick et al. 2000), sexist gender attitudes are ambivalent as they consist of two complementary and positively related ideologies: HS defined as 'an adversarial view of gender relations in which women are perceived as seeking to control 
men' (Glick and Fiske 2001, p. 109) and BS defined as positive but still patronising beliefs about women (Glick and Fiske 2001). The function of both types of sexism serves hierarchy stabilisation and therefore the maintenance of gender inequality (Glick and Fiske 2001, Sibley et al. 2007a, Becker 2010). Egalitarian gender attitudes, on the other hand, reflect ideologies which promote gender equality (McDaniel 2008). Cross-national research on ambivalent sexism reveals a 'regional' pattern: out of 19 countries, Australia, England, the Netherlands and the USA where amongst the least sexist whilst Botswana, Cuba, Nigeria and SA scored most sexist (Glick et al. 2000). In addition, gender inequality, as assessed by the Gender Empowerment Measure (GEM) and the Gender- related Development Index (GDI), correlates with HS and BS and is the highest amongst the latter group of countries (Glick et al. 2000).

However, the findings concerning SA are now more than 10 years old, and they have also never been systematically compared against PL. Due to the similarities and differences in their respective transitions we argue that varied levels of benevolent and HS will be observed in these two countries. The UK, on the other hand, may not be considered a country undergoing, or recently having undergone, transition. That is to say, its relatively stable democratic political system has spanned some 300 years in comparison to PL and SA's mere 20. It is also well-researched and has consistently scored amongst the most egalitarian countries worldwide (Williams and Best 1990, Glick et al. 2000, 2004). The UK has therefore been included in this study as a useful benchmark against which the less well-researched transitional countries of PL and SA may be compared. It should, however, be acknowledged that levels of gender equalitarianism in the UK are exceeded in North European countries. While there is lack of research testing (ambivalent) sexism in countries such as Iceland, Finland, Norway or Sweden they consistently score as the most egalitarian countries worldwide on various gender equality indices (Brandt and Henry 2012, Prewitt-Freilino et al. 2012). Further research might therefore compare countries in transition with these types of countries.

\section{Comparing sexist attitudes towards women in PL, SA and the UK}

Given the aforementioned correlation between both GEM and GDI with ambivalent sexism (Glick et al. 2000), it is arguable that sexism in the three countries might be predicted on the basis of such indices (Glick et al. 2000). However, whilst the most recent GEM analysis ranks the UK as most egalitarian (15th worldwide, 0.79), followed by SA (26th worldwide, 0.687) and then PL (38th worldwide, 0.631), the last GDI analysis ranks the UK as most egalitarian (17th worldwide, 0.943), followed by PL (39th worldwide,

0.877 ) and then SA (109th worldwide, 0.680) (Glick et al. 2000, United Nations Development Programme 2009). These inconsistencies may partly be explained by the different aspects of equality that they measure. But they may also indicate the complexities and variability in gender attitudes typical of societies in transition (Bhana et al. 2008). Indeed, the only country out of the three, which scores consistently highly on both socioeconomic and psychological measures of egalitarianism is the relatively socioeconomically stable and non-transitional UK.

Notably, the UK is also considered to be amongst the most developed countries in the world. Modernisation manifests itself in numerous ways, including for example, industrialisation, technological sophistication, economic development, etc. This is argued to be related to higher levels of gender equality (Williams and Best 1990, Inglehart and Norris 2003). The feminist movement in the UK dates back to approximately the early 1800s. ${ }^{1}$ However, considerable reduction in egalitarian trends since the early 1980s is 
This is an Accepted Manuscript of an article published by Taylor \& Francis in Journal of Gender Studies on June $3^{\text {rd }}, 2013$, available online: http://doi.org/10.1080/09589236.2013.803952

reported by some commentators in the UK (Blau et al. 2006, Scott 2006, Dorius and Alwin 2010) while others even debate the possibility of trend reversal or a return to sexism (Crompton et al. 2005, Braun and Scott 2009, Walter 2010).

How does the UK compare to SA and PL in terms of sexist attitudes? Although, given the above, the level of egalitarianism in the UK might have decreased since Glick et al.'s (2000) first results, it is reasonable to expect that it is still significantly more egalitarian than SA and, possibly, PL. SA scored amongst the most conservative countries in earlier cross-national research concerning ambivalent sexism (Glick et al. 2000). A recent study involving young Mixed race and Black males from a South African township reports between 50\% and 80\% agreement with the HS scale (Kalichman et al. 2007).

Existing evidence for greater egalitarianism of the UK compared to PL is of an indirect nature only. The few cross-national studies which include CEE countries and use gender attitude measures (Frieze et al. 2003, Levant et al. 2003, Shafiro et al. 2003) have demonstrated their greater gender conservatism as compared to Western nations. However, such studies largely neglect consideration of PL. Few studies have compared PL to other CEE countries and, those which have (Forbes et al. 2004, Robila and Krishnakumar 2004, Olson et al. 2007), suggest that PL ranks relatively moderately on measures of gender attitudes and equality. To the best of our knowledge, only one cross- national study included PL and assessed both hostile and benevolent attitudes towards women using the Ambivalent Sexism Inventory (ASI; Glick and Fiske 1996). It reported higher sexism in Polish than in American students (Forbes et al. 2004). However, Forbes et al.'s (2004) study included only female participants. Existing research indicates that the UK scores similarly to the USA on HS and lower on BS (Glick et al. 2000). Therefore, taken together, and along with modernisation theories, the studies by Forbes et al. (2004) and Glick et al. (2000) suggest that, similarly to SA, PL will score as more sexist than the UK.

The question concerning how PL and SA compare to each other is more difficult to answer due to a paucity of research. These countries are described as societies in transition; both underwent long struggles for independence, dynamic socio-economic changes and represent relatively young democratic systems established in the early 1990s following intervals of economic and political isolation (Burgess and Steenkamp 1999, Grodsky 2011). One could predict a comparable level of sexism in these countries based on modernisation theories (Inglehart and Norris 2003) and, as mentioned above, AST is underspecified in this regard. Yet, as already noted, our analysis allows us to go beyond these theories and to make more precise predictions concerning the manifestation of ambivalent sexism in each country.

In SA's case, transition towards democracy, seen in the movement from apartheid to majority political rule after democratic elections in 1994, resulted in gender equality concerns being placed at the centre of democratisation debates (Andrews 2001, Hassim 2002, 2004, Jagwanth and Murray 2002). Greater legal and political equality for women resulted from direct feminist participation in the processes of transition (Hassim 2005); even though some claim that democratisation has ushered only moderate improvement in equality at grassroots level (Hassim 2004). PL's transition towards democracy was quite distinct from that of SA. Idealist Marxist-Leninist theories of women's equality informed communist values (Yakushko 2005). This apparent egalitarianism in the public sphere was, however, not accompanied by equality in the domestic sphere (Shafiro et al. 2003). Polish women experienced the so-called 'triple burden' - the roles of worker, mother and social activist (LaFont 2001). Transition towards patriarchal democracy in 1989 was marked therefore by a rejection of communist ideals. This included denunciation of 
previously politically fostered ideologies of women's emancipation. Reinforcement of the ideals of motherhood and the remasculinisation of society resulted in the loss of egalitarian gains made under the communist dispensation (Wall et al. 1999, LaFont 2001, Pollert 2003, Yakushko 2005, Seguino 2007). Polish feminist movements continue to be less well established than those in most Western countries as well as, notably, SA (Rosner 1997, LaFont 2001, Ksiniewicz 2004).

Conflicting factors are thus at work in PL but perhaps less so in SA. The process of modernisation (Inglehart and Norris 2003) and liberal individualism promoted by (patriarchal) capitalism (Gibbons et al. 1991) both facilitate more liberal gender roles in PL as well as in SA. However, while women's issues were central to the democratisation process in SA (Hassim 2004), they were marginalised in PL (LaFont 2001, Pollert 2003, Seguino 2007). This analysis suggests greater likely development of egalitarianism in SA than in PL over the same period.

Given that, according to AST (Glick and Fiske 1996), HS and BS are two complementary facets of traditional gender ideology, we expect that PL and SA will score as significantly more sexist than the UK on both HS (H1a) and BS (H1b). We also predict that, due to their specific histories of transition, PL will score higher than SA on both HS (H1c) and BS (H1d). While the former two hypotheses are based on previous crosscultural research on AST, the latter two go beyond the theory and are based on our argument as outlined above. Importantly, however, AST suggests that men and women may score differently on specific forms of sexism within each country.

\section{Gender differences in sexist attitudes in PL, SA and the UK}

Cross-national evidence implies that women are more liberal in their gender attitudes than men. This was shown in 14 countries drawn from across North and South America, Africa, Europe and Asia (except for Malaysia and Pakistan, Williams and Best 1990) as well as for CEE in terms of overall gender equality (Olson et al. 2007) and attitudes towards women (Frieze et al. 2003, Levant et al. 2003).

The picture is more complex with regard to ambivalent attitudes and depends on the type of sexism. According to AST the two forms of sexism (HS and BS) hold different meaning for men and women (Glick and Fiske 2001, Viki and Abrams 2004, Sibley et al. 2007b, Sibley and Perry 2010). HS is overtly negative to women and threatens their ingroup interest directly. For men, on the other hand, HS is motivated by the need to protect their in-group interests (dominance) against the supposed threat to their power by women (Sibley et al. 2007b). Thus, endorsing HS protects male in-group interests, whilst rejecting it protects female in-group interests. This leads to a gender difference in HS, with men outscoring women (H2a). Such a main gender effect on HS was seen in all 19 countries examined by Glick et al. (2000).

The case of gender differences on BS is different. While the two types of sexism share the belief that women are weak and dependent upon men, they differ in that BS offers the unique promise of men's protection so long as women do not challenge the status quo (Viki and Abrams 2004). In everyday life, BS may be perceived as positive and therefore many fail to see its inherent sexism (Barreto and Ellemers 2005). However, BS has been shown to bolster HS (Sibley et al. 2007a). Even if women recognise the ill-effects of BS, they may be motivated to embrace it as it offers protection from HS - particularly in highly sexist contexts (Sibley et al. 2007a) or ' [ ... ] in times of intense social threat [ ... ], especially when alternative sources of power and resources are not readily available' (Sibley et al. 2007a, p. 745). Glick and colleagues (Glick et al. 2000, Glick and Fiske 
2001) similarly argue that in highly sexist countries women depend on men to a greater degree and the consequences of them challenging the status quo are more severe. This suggests that women in particular may embrace BS especially strongly in less egalitarian countries such as SA and PL.

Men, on the other hand, may be motivated to endorse BS to a greater extent in more egalitarian countries. In intimate relations, dominant groups are often seen to apply paternalistic ideologies, such as BS, to subordinates alongside hostile ones, as they serve as an effective tool of social control (Jackman 1994, Sibley et al. 2009). BS defines and justifies women's subordinate position and maintains their acquiescence by 'sweetening the deal' - offering a reward (such as social acceptance) for conforming to the status quo and thus reducing the need for combative HS. However, the less egalitarian a country, the more men 'may be likely to endorse HS directly, without the need for BS to function as a legitimizing [...] expressions of HS [...]' (Sibley et al. 2007b, p. 170). The need for men's expression of BS increases along with greater gender egalitarianism as expressing HS becomes socially inappropriate.

So, according to AST, unlike in the case of HS where men and women have opposing motivations to, respectively, embrace or reject it, in the case of BS both men and women are motivated to embrace it. However, women's motivation increases along with greater levels of sexism in a country, while men's motivation increases along with lower levels of sexism. This suggests that in gender conservative countries, such as SA, women should outscore men on BS (H2b) while in gender egalitarian countries, such as the UK, it is men who may embrace BS to a greater extent than women (H2c). Indeed, in line with the theory, in 19 nations, including SA and the UK, men consistently expressed HS to a greater extent than women (Glick et al. 2000). Findings concerning BS were, however, more varied. Whilst in some, mainly egalitarian, countries (such as Australia, England and the USA) men rated higher on BS than women, in other, more sexist countries (such as Cuba, Nigeria or SA), it was women who outscored men. Masser and Abrams (1999) and Viki and Abrams (2003) also consistently showed that British men outscored women on both HS and BS.

CEE countries were not included in Glick et al.’s (2000) study. Yakushko (2005) nonetheless reports that Ukrainian women embraced BS to a greater extent than men; this is typical of less gender egalitarian countries. However, these findings diverge from Glick et al.'s (2000) cross-national research in that no significant gender differences were found on HS. The only study measuring HS and BS through the use of the ASI in PL tested only females and therefore does not explore gender differences (Forbes et al. 2004). Based on this empirical literature it is unclear therefore what gender differences will emerge in PL. However, if PL is the most conservative of the three countries, as argued previously, then a pattern typical of conservative countries should emerge where Polish women outscore Polish men on BS (H2d).

\section{Methods}

\section{Participants}

Student participants were recruited through means such as campus leaflets and e-mails. They were offered remuneration for their time.

Sample 1: UK. One hundred and twenty-six British undergraduate students (40\% females and $60 \%$ males) from Royal Holloway University of London and the University of Winchester participated. Forty non-British participants were removed from an initial sample of 166 participants. British participants averaged 22.13 years of age, ranging from 
18 to 48 years old (SD $1 / 4$ 5.85). Ninety-two per cent identified as White, followed by 3\% Mixed, 2\% Black, 2\% Asian and 1\% of other ethnic origin. Most studied social sciences and the arts (76.2\%), followed by joint programmes (12.7\%), science (5.6\%) and unknown subjects $(5.6 \%)$.

Sample 2: PL. One hundred and twenty-seven Polish students (50\% females and 50\% males) from Gdansk University participated. They averaged 22.13 years of age, ranging from 19 to 29 years old (SD $1 / 4$ 2.30). All participants were White and the majority were recruited from the psychology and arts departments (83.5\%), whilst the remaining studied science (12.6\%), joint programmes (3.1\%) and unknown subjects $(0.8 \%)$.

Sample 3: SA. One hundred and seventy-five South African students (56\% females and $44 \%$ males) from the University of Cape Town participated. They averaged 19.82 years of age, ranging from 17 to 34 years old (SD $1 / 42.14$ ). Fifty-five per cent identified as White, $11.4 \%$ as Asian, $17 \%$ as Coloured or Mixed, $15.4 \%$ as Black and $1.2 \%$ as unknown or other. Students were recruited from psychology, other social sciences and arts departments (70.8\%), sciences (21.7\%), joint programmes (6.9\%) and unknown subjects $(0.6 \%)$.

Design and procedure

A 3 (country: PL, SA and the UK) $£ 2$ (participants' sex: male vs. female) betweensubjects design was adopted, where dependent variables included hostile and BS. ${ }^{2}$

Individuals participated in small groups. Each individual was provided with a booklet containing an information sheet with a cover story (i.e. that the study involved measurement validation), a consent form, the ASI (Glick and Fiske 1996) and a debriefing note which explained the real purpose of the study. The session took approximately 30 min. The study received necessary institutional ethical approval. British Psychological Society's ethical guidelines were adhered to at all times including that informed consent was obtained from all participants.

\section{Measures}

Glick and Fiske's (1996) ASI was used to measure sexist attitudes towards women. This tool contains a 6-point Likert-type response format (0 - disagree strongly; 5 - agree strongly), where half of the 22 items measure hostile and the other half measure BS (HS and BS, respectively), and higher scores indicate higher sexism. Evidence for the ASI's discriminant and convergent validity has been provided by Glick and Fiske (1996), for its cross-national validity by Glick et al. (2000) and its convergent and divergent validity in British samples by Masser and Abrams (1999). ${ }^{3}$ The scale was administered in English in SA and the UK and translated into Polish. The Polish translation was back-translated into English, and any ambiguities in the translation were resolved through discussion (see Appendix for the Polish translation). Items 4 and 8 were removed from the respective HS and BS scales due to low item-total correlations, after which satisfactory reliability coefficients were obtained. ${ }^{4}$

\section{Results}

Overview of the data

As Table 1 illustrates, participants' mean scores ranged from 1.98 to 2.81 for HS and from 2.05 to 3.07 for BS which indicates relatively low to moderate endorsement of sexism in the three samples. The scores in the UK are only slightly higher than those reported by 
Table 1. Means and standard deviations for three countries and two gender groups for HS and BS

\begin{tabular}{|c|c|c|c|c|c|c|}
\hline \multirow{2}{*}{$\begin{array}{l}\text { toward women. } \\
\text { Measure }\end{array}$} & \multicolumn{3}{|c|}{ HS } & \multicolumn{3}{|c|}{ BS } \\
\hline & M & SD & $\mathrm{n}$ & $\mathrm{M}$ & $\mathrm{SD}$ & $\mathrm{n}$ \\
\hline \multicolumn{7}{|l|}{ UK } \\
\hline Females & 1.98 & 0.87 & 50 & 2.05 & 0.80 & 50 \\
\hline Males & 2.35 & 0.87 & 76 & 2.35 & 0.67 & 76 \\
\hline Females & 2.60 & 0.93 & 63 & 2.96 & 0.88 & 63 \\
\hline PLMales & 2.81 & 0.93 & 64 & 3.07 & 0.84 & 64 \\
\hline Females & 2.14 & 0.87 & 98 & 2.52 & 0.87 & 98 \\
\hline SAMales & 2.67 & 0.90 & 77 & 2.74 & 0.81 & 77 \\
\hline
\end{tabular}

Glick et al. (2000, P. Glick, personal communication, 4 October 2011), whilst in the case of SA scores are lower than those previously reported. ${ }^{5}$ This indicates potential temporal changes in SA and the UK with attitudes becoming slightly less sexist in the former and somewhat more sexist in the latter. ${ }^{6}$

Preliminary analyses

In order to test cross-national construct equivalence a replicatory factor analysis was conducted following Ben-Porath's (1990) recommendation. Factorial solutions confirmed the original HS and BS factors in each country, providing evidence for invariance. ${ }^{7}$

\section{Main analysis}

The interdisciplinary reader may wish to advance to the section 'Analysis summary for interdisciplinary readers'. Multivariate analysis of variance was conducted by country and gender for both measures of sexism (HS and BS). Levene's test revealed no significant differences in variance for HS and BS. The multivariate test statistic using Pillai's trace indicated that there were significant main effects of country, $\mathrm{V} 1 / 40.14, F(4$, 844) $1 / 4$ 15.824, $\mathrm{p}>0.001$, and sex, V 1/4 0.044, F(2, 421) $1 / 44.751, \mathrm{p}>0.001$, but no country $£$ sex interaction effect, V $1 / 40.007, F(4,844) 1 / 40.727, p^{1 / 4} 0.574$, on both types of sexism. Separate univariate analysis of variances on the outcome variables are reported below. Descriptive statistics are reported in Table 1.

\section{Comparison of three countries on HS and BS}

Hypothesis 1a was confirmed: the follow-up analysis for the significant main country effect on HS, $\mathrm{F}(2,427) 1 / 411.612, \mathrm{p}, 0.001, \mathrm{~h}_{\mathrm{p}}^{2} 1 / 4$ 0:052, revealed that both Polish $(\mathrm{M} 1 / 4$ 2.71) and South African ( $1 / 4$ 2.41) students rated significantly higher on HS than British ones (M 1/4 2.16, p > 0.001 and p > 0.05, respectively). Moreover, Polish students also scored significantly higher than the South African ones $(p, 0.01)$ confirming H1c.

Hypotheses $1 \mathrm{~b}$ and 1d predicted similar pattern for BS which was confirmed: The follow-up for the significant main country effect on BS, F(2, 427) $1 / 430.633$, p > 0.001 , $h_{\mathrm{p}}^{2} 1 / 4$ 0:127, indicated that Polish (M $1 / 4$ 3.01) and South African (M 1/4 2.63) samples both rated significantly higher on $B S$ than the British sample $\left(M \frac{1}{4} 2.20\right.$, both $\left.p, 0.001\right)$. Moreover, PL and SA also differed significantly from each other $(p, 0.001)$ with PL scoring as more benevolently sexist than SA. 


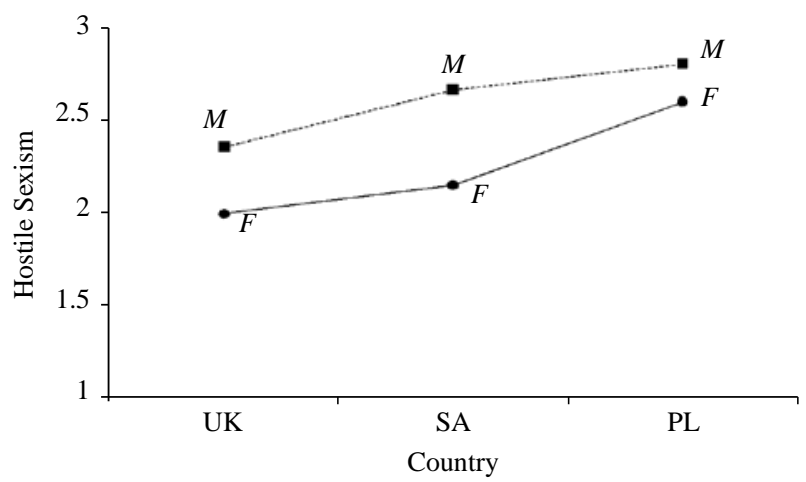

Figure 1. HS as a function of country and participants' sex.

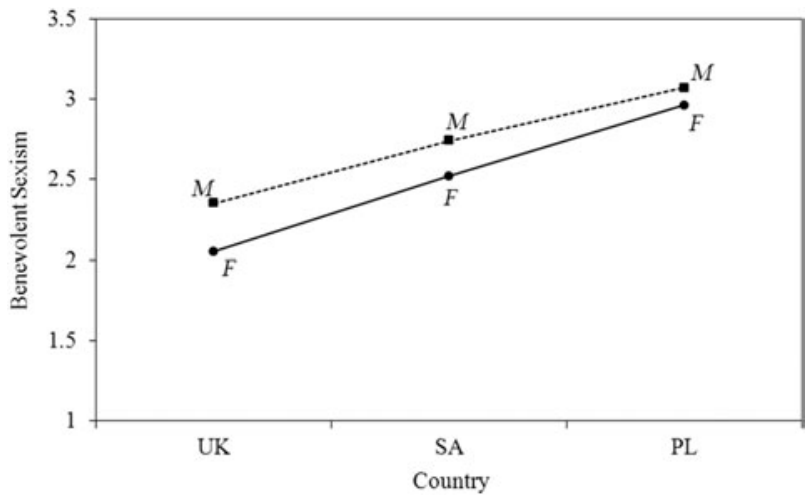

Figure 2. BS as a function of country and participants’ sex.

Testing gender differences across countries

In line with Hypotheses 2a, a significant main effect of sex on HS revealed that women rated lower on $\mathrm{HS}\left(\mathrm{M} 1 \frac{1}{4}\right.$ 2.24) than men $\left(\mathrm{M} 1 \frac{1}{4}\right.$ 2.61), $\mathrm{F}(1,422) 1 / 417.601, \mathrm{p}$, 0.001 , $h_{p}^{2} 1 / 4$ 0:04. This effect was not qualified by a country $£$ sex interaction effect, $F(2$, 422) $1 / 4$ 1.159, $\mathrm{p}-0.1, \mathrm{~h}_{\mathrm{p}}^{2} 1 / 4$ 0:005 (see Figure 1).

To test Hypotheses 2b, 2c and 2d both main effect of sex and country $£$ sex interaction were calculated for BS. The main effect of sex reached significance, $F(1,422) 1 / 46.58$, $\mathrm{p}>0.05, \mathrm{~h}_{\mathrm{p}}^{2} 1 / 4$ 0:015. Women scored lower on BS (M 1/4 2.51) than men (M 1/4 2.72). However, contrary to our predictions, this main effect was not qualified by a country $£$ sex interaction, $F(2,422) 1 / 40.372, p-0.1, h_{p}^{2} 1 / 40: 002$, indicating that this gender difference was not restricted to the relatively liberal UK (as predicted by H2c), but held also for more conservative SA and PL (contradicting H2b and H2d, respectively, see Figure 2).

Analysis summary for interdisciplinary readers

Statistical analysis was conducted in order to determine whether differences in hostile and benevolent scores between the three countries, two genders, or any combination of these, were significant and in the predicted direction. This analysis revealed that the level of both types of sexism differed significantly as a function of country. Specifically, irrespective of 
their gender, both Polish and South African students scored as significantly more hostilesexist than British ones in accordance with Hypothesis 1a. Moreover, Hypothesis 1c was also confirmed through the finding that Polish students scored as significantly more hostile-sexist than South African ones; again, irrespective of their gender. The same pattern was found for BS and therefore offered support for Hypotheses 1b and 1d.

The analysis also revealed that the level of both types of sexism differed significantly as a function of participant's gender. That is to say, irrespective of their nationality, women scored as less hostile-sexist than men in accordance with Hypothesis 2a. However, women also scored as significantly less benevolent-sexist then men across all three countries. This was a pattern that we predicted only for the relatively liberal UK. Thus, while Hypothesis 2c was supported, Hypotheses 2b and 2d were not.

\section{Discussion}

The main aim of this study was to address the dearth of cross-national research concerning the manifestation of ambivalent sexism in two under-researched transitional countries - PL and SA - and to compare them to the well-researched and socio-economically stable UK. Our analysis uniquely considers how the countries' history of transition might influence sexism, and, in doing so, goes beyond the predictions of current theories such as AST and modernisation theories. The answers to our two key research questions are discussed below.

Benevolent and hostile attitudes towards women in PL, SA and the UK

In line with our predictions, Polish and South African students were more hostile- and benevolent-sexist than British students. This finding lends support to AST's contention that the two types of sexism act as complementary ideologies (Glick and Fiske 2001). It also largely replicates cross-national findings that compare SA and the UK (Glick et al. 2000). Yet it would appear there have been slight changes over time: while South African scores show higher egalitarianism, the British scores indicate somewhat less egalitarianism. This trend in SA is consistent with the notion that modernisation leads to greater gender-egalitarianism (Inglehart and Norris 2003). The potential decline of gender-egalitarianism in the UK, while concerning, finds support in literature on the return of sexism to the UK (Crompton et al. 2005, Braun and Scott 2009, Walter 2010).

Comparative findings from PL and SA are not only unique but also interesting. These countries have both undergone dramatic socio-economic transition over the last 20 years. Modernisation theories would thus suggest similar level of progress towards egalitarianism (Inglehart and Norris 2003). AST on the other hand assumes biological and social roots of $\mathrm{HS}$ and BS and is underspecified with regards to predictions concerning cross-cultural levels of ambivalent sexism. However, our findings show that the two countries did differ significantly, with PL scoring as more gender-conservative on both types of sexism. These findings confirmed our predictions based on the historical specificities of transition in each country. We argued that since gender issues were placed at the centre of the democratisation debates in SA (Andrews 2001, Hassim 2002, 2004, Jagwanth and Murray 2002) this facilitated the development of a vibrant and effective feminist movement in that country and promoted increased gender egalitarianism in SA. Unlike SA, gender issues were marginalised in democratisation debates in PL, due to conscious distancing from the forced 'emancipation' of the communist system (LaFont 2001), which led to the remasculinisation of society (LaFont 2001, Pollert 2003, Yakushko 2005, Seguino 2007) and lack of support for gender equality. 
This is an Accepted Manuscript of an article published by Taylor \& Francis in Journal of Gender Studies on June $3^{\text {rd }}$, 2013, available online: http://doi.org/10.1080/09589236.2013.803952

While further research is needed to investigate the direct links between socio-political factors and ambivalent sexism, our findings point towards the importance of policy development in shaping gender attitudes at a national level. As illustrated here, such an analysis may be useful in extending the scope of current theories.

\section{Gender difference in sexism in PL, UK and SA}

Findings concerning HS confirmed our prediction: irrespective of country, men outscored women. While this finding is consistent with reported cross-national patterns (Glick et al. 2000), it also supports the AST's contention that men and women have different motivations in endorsing or rejecting HS. In other words, irrespective of the level of sexism in any country, endorsing HS protects male group interests and dominance (Sibley et al. 2007b). Rejecting HS, on the other hand, protects female in-group interests against the negative evaluation of their gender group (Glick and Fiske 1996). Our findings also demonstrate, for the first time, that this pattern holds for PL. They are incongruent, however, with Ukrainian findings where women were not found to differ from men on HS (Yakushko 2005). Yet these are of limited comparability as the ASI was administrated to Ukrainian students in English. Further research could fruitfully investigate variations in gender differences within these, and other CEE countries.

Our predictions for BS were partially confirmed. Men's greater endorsement of BS held not only in the egalitarian UK but also in PL as well as SA. While our findings for SA and PL contradict our predictions and earlier findings reported in Glick et al. (2000) about SA, they do not necessary challenge AST. It is possible that the level of egalitarianism in SA and PL, although lower than that in the UK, is sufficient to motivate men to endorse BS (as the only means of maintain the status quo) by already making hostility to women socially unacceptable. Indeed, in absolute terms, our scores indicate relatively low endorsement of sexist attitudes in all three samples. Moreover, compared to Glick et al.'s (2000) relatively dated findings, this study suggests potential movement towards greater egalitarianism in SA. A number of interesting questions therefore emerge. At what level does egalitarianism start motivating men to embrace BS, and further, at what level, if at all, does egalitarianism result in rejecting both types of sexism among men and women? Answers to these questions are important in order to understand the process of gender attitude liberalisation and might inform future policy development.

Novel Polish findings also illustrate a pattern typical of gender egalitarian countries (Glick et al. 2000): although this sample scored as the most gender-conservative of the three, men outscored women on both HS and BS and their absolute scores were fairly egalitarian. This pattern differs, however, from Yakushko's (2005) findings obtained from the Ukraine where women outscored men on BS. Such a score is more typical for gender conservative country and indeed the means reported by Yakushko (2005) are higher for both types of sexism than those reported in the current study for PL. More research is needed to gain a fuller picture of how Eastern European countries score on ambivalent sexism, how they compare to each other as well as to Western countries, how their particular socio-economic histories interact with these attitudes, and whether their attitudes change over time during and post transition.

Whilst choice of student samples is a common practice, as it helps to increase comparability of findings across countries, it also compromises the generalisability of the findings outside the student population. It is possible that other, older or less educated, social groups in each country are less gender egalitarian than our samples (Phinney and Flores 2002, Swim et al. 2005, Scott 2006, Dorius and Alwin 2010). Moreover, the self- 
This is an Accepted Manuscript of an article published by Taylor \& Francis in Journal of Gender Studies on June $3^{\text {rd }}$, 2013, available online: http://doi.org/10.1080/09589236.2013.803952

report measures used in this study may have returned optimistically liberal scores. Although most recent scales with improved psychometric properties were used (Swim et al. 2005), they may still be prone to social desirability effects (Nelson 2002). Even though we made use of a cover story designed to mitigate possible social desirability effects, in order to address this issue directly, the use of both implicit and explicit measures of gender attitudes is recommended in further studies (for example, Implicit Associations Test, Greenwald and Banaji 1995, Rudman and Kilianski 2000, Lane et al. 2007).

This study contributes towards our current body of knowledge by comparing ambivalent sexism to women in transitional PL and SA as well as in the UK directly for the first time. It also goes beyond current theory by emphasising that the manifestation of sexism may, to some extent at least, depend upon histories of transition. It also stressed the importance of policy development which, as the current analysis has shown, has clear potential to bring about real change towards egalitarianism. Future investigations need to include more countries undergoing transition in order to further our understanding of the manifestation of ambivalent sexism in them.

\section{Acknowledgements}

We would like to thank the University of Winchester for sponsoring this research through a Research and Knowledge Transfer Grant. We would also like to express our gratitude to the University of Gdansk in Poland and the University of Cape Town, South Africa, for their cooperation. Last, but not least, our thanks go to Dr Blu Tirohl and the anonymous reviewers for their helpful comments on earlier version of this manuscript.

\section{Notes}

1. It should be noted here that full women's suffrage was not achieved until 1928 as compared to 1918 in PL. In SA suffrage was initially granted to White women in 1930 and was fully extended to include Black women in 1994.

2. For the interdisciplinary reader: $3 £ 2$ between subject design refers to a research design where 6 groups $(3 £ 21 / 46)$ of different people (hence 'between subject') are compared on a given measured variable (called dependent variable - here level of sexism). This format contains information about the number of factors (here two: country and participants' sex) on which the measured scores may depend and the number of levels each factor is represented by (here 3 countries and 2 sexes). Interested readers may find more information about research designs in Richardson et al. (2011).

3. For the interdisciplinary reader: validity of a scale (or of a measurement tool) refers to an assessment of whether the scale measures what it was designed to measure (e.g. sexism and not racism). Support for discriminant (or divergent) validity is obtained if the measure does not correlate with (returns different scores than) a measure of an unrelated concept. Convergent validity is the opposite: evidence for it is obtained if the measure in question correlates with a different measure of the same or similar concept (see Howitt and Cramer 2011).

4. The data was tested using recognized methods in this field: a reliability analysis was carried out for both HS and BS scales using Cronbach's a test. The test assesses how well the scale measures what it is designed to measure (i.e. sexism) by examining its internal consistency (i.e. if responses to each statement/item on the scale are related). Low item-total correlations indicate that a given item/statement generates responses which do not relate well to the remaining items. Satisfactory Cronbach's a scores emerged for each country in the current study for both HS (a $a_{P L} 1 / 40.79$, $\mathrm{a}_{\mathrm{SA}} 1 / 40.83$ and $\left.\mathrm{a}_{\mathrm{UK}} 1 / 40.84\right)$ and $\mathrm{BS}\left(\mathrm{a}_{\mathrm{PL}} 1 / 40.75, \mathrm{a}_{\mathrm{SA}} 1 / 40.75\right.$ and $\mathrm{a}_{\mathrm{UK}}{ }^{1 / 4}$ 0.72) (see Field 2009).

5. The means for the UK in our study were as follows: for $\mathrm{HS}_{\mathrm{F}} \mathrm{M}^{1 / 4} 1.76$ versus $\mathrm{M}_{\mathrm{M}} 1 / 42.13$ and for BS $M_{F} 1 / 41.92$ versus $M_{M} 1 / 42.02$ while our means for SA were as follows: for $H_{S} M_{F} 1 / 42.41$ versus $M_{M} 1 / 43.44$ and for $B S M_{F} 1 / 43.45$ versus $M_{M} 1 / 43.20$.

6. Although more recent data sets exist, these, unfortunately, are not comparable to those of Glick et al.'s (2000). For example, Viki and Abrams's (2003) report more recent findings concerning the UK, and Forbes et al. (2004) for Polish females but these authors adopted modified HS and BS subscales with seven-point, as opposed to the original six-point, response format. 
This is an Accepted Manuscript of an article published by Taylor \& Francis in Journal of Gender Studies on June $3^{\text {rd }}$, 2013, available online: http://doi.org/10.1080/09589236.2013.803952

7. Construct equivalence (i.e. referring to whether the concept of sexism is understood and functions in the same way in all three countries) is operationally defined as factorial or metric invariance. This is tested through replicatory factor analysis - a statistical procedure which assesses if the responses to the items/statements in a given scale cluster around a number of a priori identified factors in the same way as in the original scale. Here existence of two factors (i.e. benevolent and hostile sexism) was assumed and confirmed. Level of similarity between the obtained factorial solutions (i.e. clusters of items) from each country was also assessed: Tucker's (1951) phi coefficient of congruence indicated that Polish and South African factors where highly similar to the British ones exceeding the recommended cut off point of 0.90 (Tucker 1951): 0.94 for HS in SA, 0.93 for BS in SA, 0.95 for HS in PL and 0.91 for BS in PL (see Ben-Porath 1990).

\section{Notes on contributors}

Magdalena Zawisza, Ph.D., is a senior lecturer in the Department of Psychology at the University of Winchester. Her research interests fall into three general areas: consumer, gender and applied social psychology. More specifically, she is interested in gender issues in advertising such as the effectiveness of (non)traditionally gender advertisements. In her more recent research, she examines explicit or implicit gender attitudes and stereotype content and their performance in advertising context. Another strand of her research focuses on attitudes to both men and women in countries undergoing transition to democracy. Her further interests include elaboration of gendered advertisements by men and women as well as the effects of gendered advertisements on audiences. Her work is grounded in positivist approach and uses mainly experimental methodology.

Russell Luyt is a senior lecturer in the Department of Psychology at the University of Winchester. He is particularly interested in identity processes as well as debates concerning research philosophy and qualitative methodology. His work is grounded within a critical approach and has, to date, focused primarily on the social psychology of gender. This has included, for example, the critique of traditional masculinity, femininity and gender measurement; media representations; masculinities and aggression; as well as the intersection of gender and other social categories. He is currently extending these lines of research and developing his interest in radicalisation among marginalised communities from a gender perspective.

Anna Maria Zawadzka is a professor at the University of Gdańsk (Poland). Her research focuses on self-regulation in the context of power, consumption, advertising and preferred values and their relationship with well-being.

\section{References}

Andrews, P.E., 2001. From gender apartheid to non-sexism: the pursuit of women's rights in South Africa. North Carolina journal of international law and commercial regulation, 26, 693-722.

Barreto, M. and Ellemers, N., 2005. The burden of benevolent sexism: how it contributes to the maintenance of gender inequalities. European journal of social psychology, 35 (5), 633-642.

Becker, J.C., 2010. Why do women endorse hostile and benevolent sexism? The role of salient female subtypes and internalization of sexist contents. Sex roles, 62, 453-467.

Ben-Porath, Y.S., 1990. Cross-cultural assessment of personality: the case for replicatory factor analysis. In: J.N. Butcher and C.D. Spielberger, eds. Advances in personality assessment. Hillsdale, NJ: Lawrence Erlbaum Associates, 27-48.

Bhana, A., Zimmerman, R. and Cupp, P., 2008. Gender role attitudes and sexual risk among adolescents in South Africa. Vulnerable children and youth studies, 3, 112-119.

Blau, F.D., Brinton, M.C. and Grusky, D.B., 2006. The declining significance of gender? New York: Russell Sage.

Brandt, M.J. and Henry, P., 2012. Gender inequality and gender differences in authoritarianism. Personality and social psychology bulletin, 38 (10), 1301-1315.

Braun, M. and Scott, J., 2009. Gender-role egalitarianism - is the trend reversal real? International journal of public opinion research, 21 (3), 362-367.

Burgess, S.M. and Steenkamp, J.E.M., 1999. Value priorities and consumer behavior in a transitional economy: a case of South Africa. In: R. Batra, ed. Marketing issues in transitional economies. Boston, MA: Kluwer Academic, 1-42. 
This is an Accepted Manuscript of an article published by Taylor \& Francis in Journal of Gender Studies on June $3^{\text {rd }}$, 2013, available online: http://doi.org/10.1080/09589236.2013.803952

Cameron, N., 2003. Physical growth in a transitional economy: the aftermath of South African apartheid. Economic human biology, 1 (1), 29-42.

Crompton, R., Brockmann, M. and Lyonette, C., 2005. Attitudes, women's employment and the domestic division of labour: a cross-national analysis of two waves. Work, employment and society, 19 (2), 213-233.

Dorius, S.F. and Alwin, D.F., 2010. The global development of egalitarian beliefs - a decomposition of trends in the nature and structure of gender ideology. Michigan: University of Michigan.

Falke, M., 2002. Community interests: an insolvency objective in transition economies? Frankfurt: Frankfurt Institute fuer Transformationsstudien.

Field, A., 2009. Discovering statistics using SPSS. London: SAGE Publications.

Forbes, G.B., et al., 2004. Association of the thin body ideal, ambivalent sexism, and self-esteem with body acceptance and the preferred body size of college women in Poland and the United States. Sex roles, 50 (5-6), 331-345.

Frieze, I.H., et al., 2003. Gender-role attitudes in university students in the United States, Slovenia, and Croatia. Psychology of women quarterly, 27, 256-261.

Gibbons, L.J., Stiles, D.A. and Shokodriani, G.M., 1991. Adolescents' attitudes toward family and gender roles: an international comparison. Sex roles, 25, 625-643.

Glick, P. and Fiske, S.T., 1996. The ambivalent sexism inventory: differentiating hostile and benevolent sexism. Journal of personality and social psychology, 70 (3), 491-512.

Glick, P. and Fiske, S.T., 2001. An ambivalent alliance: hostile and benevolent sexism as complementary justifications for gender inequality. American psychologist, 56 (2), 109-118.

Glick, P., et al., 2000. Beyond prejudice as simple antipathy: hostile and benevolent sexism across cultures. Journal of personality and social psychology, 79 (5), 765-775.

Glick, P., et al., 2004. Bad but bold: ambivalent attitudes toward men predict gender inequality in 16 nations. Journal of personality and social psychology, 86 (5), 713-728.

Greenwald, A.G. and Banaji, M.R., 1995. Implicit social cognition: attitudes, self-esteem, and stereotypes. Psychological review, 102, 4-27. doi: 10.1037/0033-295X.102.1.4

Grodsky, B., 2011. When pro-democracy organizations take power: what Poland and South Africa should have told us about Georgia [online]. Available from http://www.wilsoncenter.org/ event/when-pro-democracy-organizations-take-power-what-poland-and-south-africa-shouldhave-told-us

Hassim, S., 2002. 'A conspiracy of women’: the women’s movement in South Africa's transition to democracy. Social research, 69, 693-732.

Hassim, S., 2004. A virtuous circle? Gender equality and representation in South Africa. In: J. Daniel, R. Southall and J. Lutchman, eds. State of the nation 2004-2005. Cape Town: HSRC Press, 336-359.

Hassim, S., 2005. Nationalism displaced: citizenship discourses in transition. In: A. Gouws, ed. (Un)thinking citizenship: feminist debates in contemporary South Africa. Cape Town: University of Cape Town Press, 55-69.

Howitt, D. and Cramer, D., 2011. Introduction to research methods in psychology. Harlow: Pearson Education.

Inglehart, R. and Norris, P., 2003. Introduction: explaining the rising tide of gender equality. In: R. Inglehart and P. Norris, eds. Rising tide: gender equality and cultural change around the world. Cambridge: Cambridge University Press, 1-28.

Jackman, M.R., 1994. The velvet glove: paternalism and conflict in gender, class and race relations. Berkeley: University of California Press.

Jagwanth, S. and Murray, C., 2002. Ten years of transformation: how has gender equality in South Africa fared? Canadian journal of women and the law, 14, 255-299.

Kalichman, S.C., et al., 2007. Sexual assault, sexual risks and gender attitudes in a community sample of South African men. AIDS care, 19, 20-27.

Ksiniewicz, M., 2004. Specyfika polskiego feminizmu [Specificity of Polish feminism]. Kultura i Historia, 6, 90-100.

LaFont, S., 2001. One step forward, two steps back: women in the post-communist states. Communist and post-communist studies, 34 (2), 203-220.

Lane, K.A., et al., 2007. Understanding and using the Implicit Association Test: IV. In: B. Wittenbrink and N. Schwartz, eds. Implicit measures of attitudes. London: The Guilford Press, 59-102. 
This is an Accepted Manuscript of an article published by Taylor \& Francis in Journal of Gender Studies on June $3^{\text {rd }}$, 2013, available online: http://doi.org/10.1080/09589236.2013.803952

Levant, R.F., et al., 2003. Masculinity ideology among Russian and U.S. young men and women and its relationship to unhealthy lifestyle habits among young Russian men. Psychology of men \& masculinity, 4 (1), 26-36.

Masser, B. and Abrams, D., 1999. Contemporary sexism: the relationships among hostility, benevolence, and neosexism. Psychology of women quarterly, 23, 503-517.

McDaniel, A.E., 2008. Measuring gender egalitarianism: the attitudinal differences between men and women. International journal of sociology, 38 (1), 58-80.

Nelson, T.D., 2002. The psychology of prejudice. Needham Heights, MA: Allyn \& Bacon.

Olson, J., et al., 2007. Beliefs in equality for women and men as related to economic factors in central and eastern Europe and the United States. Sex roles, 56 (5-6), 297-308.

Phinney, J.S. and Flores, J., 2002. 'Unpackaging' acculturation: aspects of acculturation as predictors of traditional sex role attitudes. Journal of cross-cultural psychology, 33, 320-331.

Pollert, A., 2003. Women, work and equal opportunities in post-communist transition. Work, employment and society, 17 (2), 331-357.

Prewitt-Freilino, J.L., Caswell, T.A. and Laakso, E.K., 2012. The gendering of language: a comparison of gender equality in countries with gendered, natural gender, and genderless languages. Sex roles, 66, 1-14.

Richardson, P., Goodwin, A. and Vine, E., 2011. Research methods and design in psychology. Exeter: Learning Matters.

Robila, M. and Krishnakumar, A., 2004. The role of children in Eastern European families. Children \& society volume, $18,30-41$.

Rosner, K., 1997. Czy istnieje w polsce ruch feministyczny? [Does the feminist movement exist in poland?]. Pelnym glosem, 5, 13-27.

Rudman, L.A. and Kilianski, S.E., 2000. Implicit and explicit attitudes towards female authority. Personality and social psychologybulletin, 26, 1315-1328. doi: 10.1177/0146167200263001

Scott, J., 2006. Family and gender roles: how attitudes are changing, GeNet working paper no. 21.

Seguino, S., 2007. Plusça change? Evidence on global trends in gender norms and stereotypes. Feminist economics, 13 (2), 1-28.

Shafiro, M.V., Himelein, M.J. and Best, D.L., 2003. Ukrainian and U.S. American females: differences in individualism/collectivism and gender attitudes. Journal of cross-cultural psychology, 34 (3), 297-303.

Sibley, C.G., Overall, N.C. and Duckitt, J., 2007a. When women become more hostilely sexist toward their gender: the system-justifying effect of benevolent sexism. Sex roles, 57 (9), $743-754$.

Sibley, C.G. and Perry, R., 2010. An opposing process model of benevolent sexism. Sex roles, 62, $438-452$.

Sibley, C.G., Wilson, M.S. and Duckitt, J., 2007b. Antecedences of men's hostile and benevolent sexism: the dual roles of social dominance orientation and right-wing authoritarianism. Personality and social psychologybulletin, 33 (2), 160-172.

Sibley, C.G., et al., 2009. Your sexism predicts my sexism: perceptions of men's (but not women’s) sexism affects one's own sexism over time. Sex roles, 60 (9), 682-693.

Smith, P.B. and Bond, M.H., 1999. Culture: the neglected concept. In: P.B. Smith and M.H. Bond, eds. Social psychology across cultures: analysis and perspectives. Boston, MA: Allyn \& Bacon, 38-69.

Swim, J.K. and Campbell, B., 2003. Sexism: attitudes, beliefs, and behaviors. In: R. Brown and S. Gaerthner, eds. Blackwell handbook of social psychology - intergroup processes. Oxford: Blackwell Publishing, 218-237.

Swim, J.K., et al., 2005. Judgments of sexism: a comparison of the subtlety of sexism measures and sources of variability in judgments of sexism. Psychology of women quarterly, 29, 406-411.

Tougas, F., et al., 1995. Neosexism: plus ça change, plus c'est pareil. Personality and social psychology bulletin, 21, 842-849.

Tucker, L.R., 1951. A method for synthesis of factor analysis studies. Washington, DC: Department of the Army.

Twenge, J.M., 2001. Changes in women's assertiveness in response to status and roles: a crosstemporal meta-analysis 1931-1933. Journal of personality and social psychology, 81 (1), 133-145.

United Nations Development Programme (UNDP), 2009. Human development report. Overcoming barriers: human mobility and development. [Consultado 23 Febrero 2011]. 
Viki, G.T. and Abrams, D., 2003. Infra-humanization: ambivalent sexism and the attribution of primary and secondary emotions to women. Journal of experimental social psychology, 39 (5), 492-499.

Viki, G.T. and Abrams, D., 2004. Hostile and benevolent sexism: complementary system justifying ideologies. Social psychological review, 6 (2), 76-88.

Wall, S.N., et al., 1999. Gender role and religion as predictors of attitude toward abortion in Croatia, Slovenia, the Czech Republic, and the United States. Journal of cross-cultural psychology, 30, $443-465$.

Walter, N., 2010. Living dolls, the return of sexism. London: Virago Press.

Williams, J.E. and Best, D.L., 1982. Measuring sex stereotypes: a thirty-nation study. Beverly Hills, CA: Sage.

Williams, J.E. and Best, D.L., 1990. Measuring sex stereotypes: a multination study. Beverly Hills, CA: Sage.

Williams, J.E., Satterwhite, R.C. and Best, D.L., 1999. Pancultural gender stereotypes revisited: the five factor model. Sex roles: A journal of research, 40 (7-8), 513-525.

Yakushko, O., 2005. Ambivalent sexism and relationship patterns among women and men in Ukraine. Sex roles, 52 (9-10), 586-596. 
Appendix: Polish translation of the Ambivalent Sexism Scale by Glick and Fiske (1996)

Określ swoje odczucia dotyczęce każdego z podanych stwierdzeń

\begin{tabular}{|c|c|c|c|c|c|c|}
\hline Stwierdzenie & 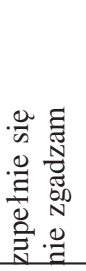 & 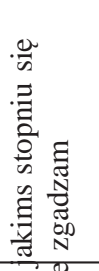 & 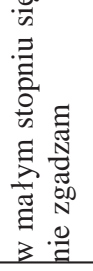 & 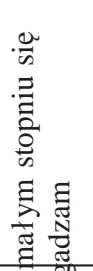 & 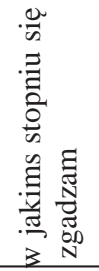 & 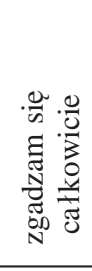 \\
\hline $\begin{array}{l}\text { 1. Mężczyzna, bez względu jak wiele } \\
\text { osięgnęł, nie jest całkowicie spełniony } \\
\text { jako osoba jeżeli nie jest kochany przez } \\
\text { kobiete. }\end{array}$ & 0 & $3 \cdot \frac{9}{7}$ & 2 & 3 & 4 & 5 \\
\hline $\begin{array}{l}\text { 2. Tak na prawde wiele kobiet zabiega o } \\
\text { specjalne względy, na przykład wykor- } \\
\text { zystujac zasady majęce na celu przynie- } \\
\text { sienie korzyści im a nie mężczyznom, pod } \\
\text { pretekstem "równouprawnienia”. }\end{array}$ & 0 & 1 & 2 & 3 & 4 & 5 \\
\hline $\begin{array}{l}\text { 3. W przypadku katastrofy, niekoniecznie } \\
\text { powinno się ratować kobiety w pierwszej } \\
\text { kolejności, przed mężczyznami. }\end{array}$ & 0 & 1 & 2 & 3 & 4 & 5 \\
\hline $\begin{array}{l}\text { 4. Wiekkszość kobiet interpretuje niewinne } \\
\text { uwagi czy uczynki jako seksistowskie. }\end{array}$ & 0 & 1 & 2 & 3 & 4 & 5 \\
\hline 5. Kobiety za szybko się obrażaje. & 0 & 1 & 2 & 3 & 4 & 5 \\
\hline $\begin{array}{l}\text { 6. Ludzie sę często naprawdę szczęśliwi w } \\
\text { życiu bez romantycznego zaangażowania } \\
\text { w osobę przeciwnej płci. }\end{array}$ & 0 & 1 & 2 & 3 & 4 & 5 \\
\hline $\begin{array}{l}\text { 7. Feministki nie dężę do uzyskania większej } \\
\text { władzy dla kobiet niz dla mężczyzn.. }\end{array}$ & 0 & 1 & 2 & 3 & 4 & 5 \\
\hline $\begin{array}{l}\text { 8. Wiele kobiet posiada cechę moralnej } \\
\text { czystosci, którę posiada niewiele mężc- } \\
\text { zyzn. }\end{array}$ & 0 & 1 & 2 & 3 & 4 & 5 \\
\hline $\begin{array}{l}\text { 9. Kobiety powinny być otaczane troska i } \\
\text { chronione przez mężczyzn.. }\end{array}$ & 0 & 1 & 2 & 3 & 4 & 5 \\
\hline
\end{tabular}

10. Większość kobiet nie docenia w pełni wszystkiego co robię dla nich mężczyźni.

11. Kobiety staraję się zdobyć władzę przez $\quad \begin{array}{lllllll}0 & 1 & 2 & 3 & 4 & 5\end{array}$ uzyskanie kontroli nad mężczyznami.

12. Każdy mężczyzna powinien mieć kobietę, $\begin{array}{lllllll}0 & 1 & 2 & 3 & 4 & 5\end{array}$ które uwielbia.

13. Mężczyźni nie potrzebuja kobiet by czuc $\quad \begin{array}{lllllll}0 & 1 & 2 & 3 & 4 & 5\end{array}$ się spełnieni.

14. Kobiety wyolbrzymiaje problemy, które $\quad \begin{array}{lllllll}0 & 1 & 2 & 3 & 4 & 5\end{array}$ maje w pracy.

15. Kiedy już kobieta zdobędzie mężczyznę, $\quad \begin{array}{lllllll}0 & 1 & 2 & 3 & 4 & 5\end{array}$ zwykle próbuje krótko go trzymać.

16. Kiedy kobiety przegrywaję z mężczyznami $\quad \begin{array}{lllllll}0 & 1 & 2 & 3 & 4 & 5\end{array}$ w sprawiedliwej rywalizacji, zwykle skarże się że se dyskryminowane.

17. Dobra kobieta powinna być stawiana na piedestale przez swojego mężczyznę. 
18 Tak na nraxsde hardan nioxsiole knhiot

czerpie satysfakcje prowokujac mezczyzn seksualnie po to tylko by potem odrzucic ich zaloty.

19. W porównaniu z mężczyznami, kobiety maje większę wrażliwość moralnę.

20. Mężczyźni powinni chętnie poświęcić swój własny dobrobyt na rzecz finansowego utrzymania swoich kobiet.

21. Feministki zgłaszaję całkowicie uzasadnione wymagania w stosunku do mężczyzn.

22. W porównaniu z mężczyznami, kobiety maję bardziej wyrafinowane wyczucie kultury i dobry gust.
n
1
$\gamma$
3
4
5

$\begin{array}{llllll}0 & 1 & 2 & 3 & 4 & 5 \\ 0 & 1 & 2 & 3 & 4 & 5\end{array}$

$\begin{array}{llllll}0 & 1 & 2 & 3 & 4 & 5\end{array}$

$\begin{array}{llllll}0 & 1 & 2 & 3 & 4 & 5\end{array}$

